\title{
Clinical and pathological studies on nutritional fibrous osteodystrophy in goats
}

\author{
Özlem ÖZMEN ${ }^{1}$, Sima ŞAHINDURAN², Ahmet AYDOĞAN ${ }^{3}$, Necmettin Sarp SEVGISUNAR ${ }^{2}$, \\ Mehmet HALIGÜR ${ }^{3}$
}

${ }^{1}$ Mehmet Akif Ersoy University, Faculty of Veterinary Medicine, Department of Pathology; ${ }^{2}$ Department of Internal Medicine,
Burdur; ${ }^{3}$ Çukurova University, Faculty of Ceyhan Veterinary Medicine, Department of Pathology, Adana, Turkey.

Summary: Fibrous osteodystrophy is a metabolic disease that characterized marked bone resorption with fibrous tissue proliferations, cysts formations and insufficient mineralization of immature bone. Nutritional fibrous osteodystrophy was developed in 37 goats from two different goat flocks in Isparta in Turkey. The aim of this study was to examine clinicopathological findings and treatment of this rare disease. Affected animals were between 2-4 months of age and were normal at birth. Clinical signs were started about 2 months of age and characterized by mandibular and maxillary enlargements, softening of the bones (especially facial bones), varying degrees of mouth opening and protruding tongue, dyspnea, leg deformities, exophthalmos, and mastication problems. Exophthalmos was seen in 13 kids due to enlargement of facial bones into the cavum orbita. Leg deformities were observed in 11 kids and they had walking problems. Blood calcium, phosphorus, magnesium, alkaline phosphatase, vitamin D3 and parathormone levels were examined. Affected animals had increased levels of phosphorus and parathormone, as well as higher alkaline phosphatase activity. 23 kids died from the disease and 10 of them were necropsied. At necropsy, bilateral enlargement of the maxilla and mandibula, leg deformities and incomplete rib fractures were observed in kids. Histopathologically, severe diffuse proliferation of loose connective tissue surrounded the osteoid trabeculae, many of which were partially or completely non mineralized and accompanied by numerous osteoclastic giant cells. Soil analysis of the pasture revealed marked decrease in calcium level (1\%). The newly born and under the one month of age kids in the flocks (totally 527 goat kids) were treated with Ca and Vit D. No new cases were observed after treatment.

Keywords: Blood biochemistry, goat, nutritional fibrous osteodystrophy, pathology, soil analysis.

\section{Keçilerde nutrisyonel fibröz osteodistrofide klinik ve patolojik incelemeler}

Özet: Fibröz osteodistrofi belirgin kemik rezorpsiyonu ile birlikte fibröz bağ doku proliferasyonları, kist formasyonları ve olgunlaşmamış kemik dokunun yetersiz mineralizasyonu ile karakterize metabolik bir hastalıktır. Isparta ilinde iki farklı keçi sürüsündeki 37 oğlakta nutrisyonel fibröz osteodistrofi saptandı. Bu çalışmanın amacı, keçilerde nadir rastlanan fibröz osteodistrofideki klinikopatolojik bulgular ile bu hastalığın tedavisinin incelenmesidir. Hasta hayvanlar 2-4 aylıktı ve doğduklarında normal görünümdeydiler. Klinik belirtiler hayvanlar yaklaşık 2 aylıkken başlayıp; mandibular ve maksiller genişlemeler, kemiklerde (özellikle yüz kemikleri) yumuşama, ağzın değişik derecelerde açık kalması ve dilin dışarıya sarkması, nefes darlı̆̆ , bacak deformiteleri, ekzoftalmus ve çiğneme problemleri ile karakterize bir tablo ile seyrediyordu. 13 oğlakta yüz kemiklerinin orbita çukuruna doğru genişlemesi sebebiyle ekzoftalmus şekillenmişti. 11 oğlakta bacak deformiteleri oluşmuştu ve bu hayvanlarda yürüme problemleri gözlendi. Kan kalsiyum, fosfor, magnezyum, alkalen fosfataz, vitamin D3 ve parathormon seviyeleri incelendi. Hasta hayvanlarda alkalen fosfataz, fosfor ve parathormon seviyeleri yükselmişti. Hastalıktan 23 oğlak öldü ve bunlardan 10'unun nekropsisi yapıldı. Nekropside, maksilla ve mandibulada bilateral şişkinlikler, bacak deformiteleri ve kaburgalardaki kırıklarda yetersiz kaynaşmalar gözlendi. Histopatolojik olarak çoğunluğu veya tamamı nonmineralize osteoid trabekülalar çevresinde yoğun gevşek bağ doku proliferasyonları ile birlikte çok sayıda osteoklastik dev hücreler dikkati çekti. Meranın toprak analizinde toprak kalsiyum düzeyinde belirgin bir eksiklik saptandı (\%1). Sürüdeki yeni doğan ve bir aylıktan küçük oğlaklar (toplam 527 oğlak) Ca ve Vit D ile tedavi edildi. Tedavi sonrası yeni vakalar saptanmadi.

Anahtar sözcükler: Kan biyokimyası, keçi, nutrisyonel fibröz osteodistrofi, patoloji, toprak analizi.

\section{Introduction}

Fibrous osteodystrophy (osteodystrophia fibrosa or osteitis fibrosa cystica) is a rare metabolic bone disorder that characterized by marked bone resorption, fibrous connective tissues proliferation, cysts formations and insufficient mineralization of the immature bone tissues.
The main cause of the osteodystrophy is the continuous and extensive action of parathormone (PTH) on bones. The pathogenesis involves the persistent increase of this hormone levels in the plasma, which may be associated with primary or secondary hyperparathyroidism $(9,22)$. In fibrous osteodystrophy, bones such as mandible and 
maxilla that with higher turnover are gradually soften and become flexible and deformed. Bones become considerably enlarged and easily fractured. They are painful when bearing weight. At the radiologic examination, widespread areas of rarefaction and cystic spaces in them may be seen $(11,14,18,23,25,27)$.

In humans, the disease has been known as vonRecklinghausen disease. Different animal species may be varying in their susceptibility to fibrous osteodystrophy. The disease is frequently observed in horses $(8,14)$ and sporadically described in goats $(2-4,27)$, rabbits (5), cats (9), dogs $(11,15,16)$, camels (13), guinea pigs (18), fox (24), lemur (23) and birds (1) in different countries; but, there is no report about fibrous osteodystrophy in goats in Turkey. The aim of this study was to examine clinical and pathological findings in goat kids suffer from nutritional fibrous osteodystrophy and prophylactic treatment with $\mathrm{Ca}$ and Vit D.

\section{Materials and Methods}

37 hair goat kids from two different flocks each consisting of approximately 550-750 animals were brought to Veterinary Education Research and Practice Hospital. For diagnosis, 10 of the goat kids were presented to Department of Pathology; seven of them were died and three of the animals were in coma. Necropsy was performed on all kids that aged between 2-4 months. In addition, blood samples were taken from the 22 affected animals. For control blood samples were also collected 5 normal, same age and breed kids. MS9 blood counting equipment was used for hematological analysis of the blood drawn in EDTA tubes (17). Blood calcium, phosphorus, magnesium and alkaline phosphatase (ALP) levels were analyzed in serum samples using IDEXX VetTest equipment and reagents. Vitamin $\mathrm{D}$ and parathormone samples were analyzed using Roche Cobas E601 equipment (by ECLIA method) (7).

After euthanasia, all organs were removed and examined grossly. Visceral organs and bone samples taken from mandible, maxilla, ribs and leg bones during the necropsy were fixed in $10 \%$ buffered formalin. While some bone samples decalcified in Osteodec decalcifying solution (Bio-Optica), most of them were soft and no need to decalcification. Using standard methods, tissues were blocked in paraffin and cut to $5 \mu$ thickness. Tissue sections were stained with Hematoxylin-Eosin (HE) (12) and examined microscopically. Soil samples collected from five sites of the pasture were analyzed for Ca levels by Scheibler method (6). After diagnosis, surviving animals were treated with $\mathrm{Ca}$ and Vit $\mathrm{D}$.

\section{Results}

Both of the farms located in Isparta, Turkey, approximately $7.0 \%$ morbidity and $90 \%$ mortality were seen in the flocks. Clinical signs included mandibular and maxillary symmetric hard swellings of the both side of the face, leg deformities, bone softening, varying degrees of mouth opening and protruding tongue, dyspnea, abnormalities of mastication and difficulty of food intake, bilateral exophthalmos and death. Leg deformations and incoordination were the other common findings (Figure 1A). The goats were rearing in the pasture and no other food additive such as brand given the animals. The owners stated that kids were normally at birth and approximately 2 months of age the symptoms were begin to appear. Most of the affected kids died from illness until 5 months of age. In flocks moved to the pasture from another region 4-5 years ago, the symptoms had been observed in a year after moving and had become worse over the years. None of the private veterinarian was able to solve problem. For that reason animals presented to Faculty of Veterinary Medicine for diagnosis and treatment.

There was no abnormality in analysis of hemogram. Blood biochemistry findings revealed normal $\mathrm{Mg}$, low $\mathrm{Ca}$ and high $\mathrm{P}$ levels. In addition to them, very low Vitamin $\mathrm{D}_{3}$ levels but high ALP levels and extremely high PTH levels were found. Blood biochemistry results of affected and control kids shown in Table 1 and soil analysis results were given in Table 2 .

At necropsy, the most common findings were varied degrees of facial enlargement, exophthalmos, softening of all bones and leg deformity (Figures 1B-C). Because of the partial mouth opening, protruding tongue, difficulty in food intake and mastication, all of the death kids had loss of general body condition. Macroscopically, jaw bones were soft, elastic and easily cut with a knife. All of the bones, especially facial bones were affected. Skull bones were soft and thinner than normal. Bilateral symmetric hard masses observed on the face (Figure 1D).

Histologically, the amount of bone tissue was reduced and replaced with connective tissue. The process was so advanced that only a small part of bone tissue has remained. At the microscopical examinations of the mandibular and maxillar bones, diffuse proliferations of soft and irregular fibrous connective tissue were observed. Most of the osteoid trabeculaes were partially or completely demineralized. Microscopic examination of the affected areas of facial bones revealed a minor disarray of the chondrocytes and consisted mainly of pink-staining osteoid with minor evidence of calcification. Osteoblasts were arranged along the margins of osteoid trabeculae. Osteoclastic activity was most prominent adjacent to the cortex of the bones. There was a scarcity of cellular elements in the marrow cavity, and in many areas, especially adjacent to the cortices there was a marked overgrowth of capillaries and fibrous tissue. In affected bones trabeculae, numerous osteoclastic multinucleated cells were observed (Figures 2A-B). Histological changes were not detected in the renal parenchyma or in the parathyroid glands. The visceral organs were normal at gross and histopathological examination. 


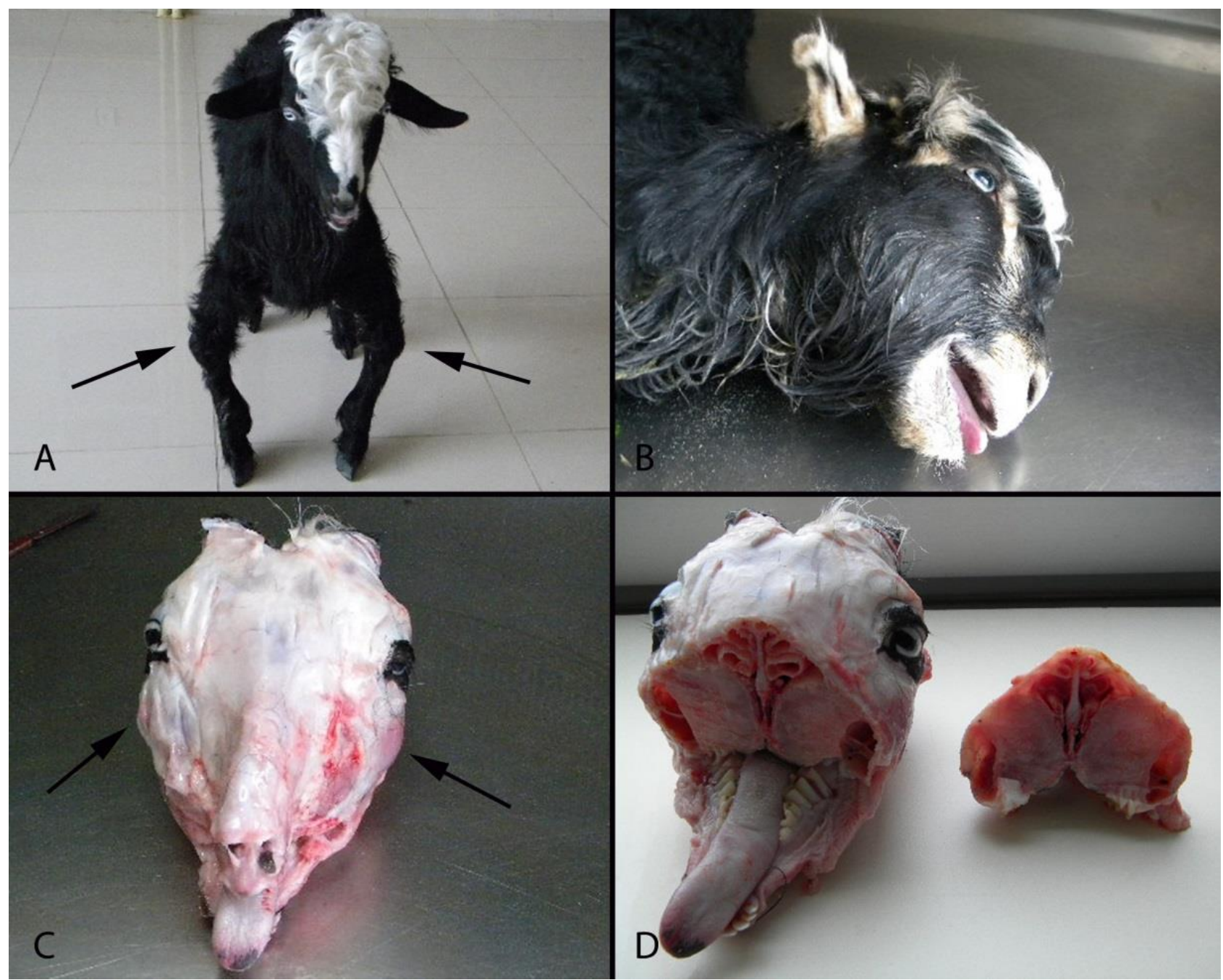

Figure 1. A. Marked facial enlargement, exophthalmos and leg deformities (arrows) in a kid. B. Protrusion of the tongue and facial swelling in another kid. C. Gross appearance of face in a kid with nutritional osteodystrophy, facial decalcified bones (arrows). D. Transversal section of the facial bones, demineralized masses, soft and thinner skull and jaw bones.

Şekil 1. A. Bir oğlakta yüzde belirgin şişkinlik, ekzoftalmus ve bacak deformiteleri (oklar). B. Başka bir oğlakta ağzın açık kalmış görünümü ve yüzde şişkinlik. C. Nutrisyonel distrofili bir oğlağın yüzünün makro görüntüsü, yüzde dekalsifiye kemikler (oklar). D. Yüz kemiklerinin transversal kesiti, demineralize kitleler, yumuşak ve incelmiş kafatası ve çene kemikleri.

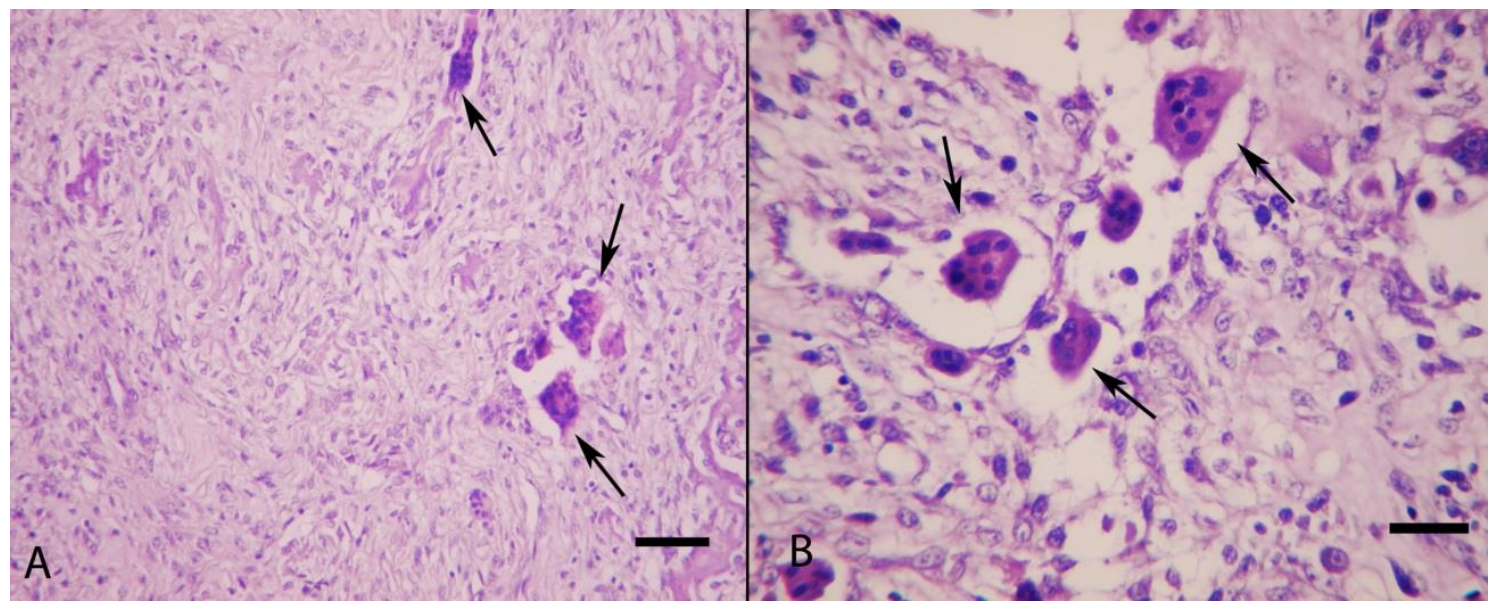

Figure 2. A. Histopathological appearance of the soft bones, bone tissue completely replaced to connective tissue and giant cells (arrows) are clearly seen, HE, Bar $=200 \mu \mathrm{m}$. B. Numerous osteoclastic giant cells (arrows) that present in newly formed fibrous tissue in the bones, HE, Bar $=100 \mu \mathrm{m}$.

Şekil 2. A. Yumuşamıș kemiklerin histopatolojik görünümü, tamamen bağ dokuya dönüşmüş kemik doku ve osteoklastik dev hücreler (oklar), HE, Bar $=200 \mu \mathrm{m}$. B. Kemiklerde yeni şekillenen fibröz bağ dokudaki çok sayıdaki osteoklastik dev hücreler (oklar), HE, $\mathrm{Bar}=100 \mu \mathrm{m}$. 
Table 1. Blood biochemistry results of affected and control goat kids.

Tablo 1. Hasta ve kontrol oğlakların kan biyokimyası sonuçları.

\begin{tabular}{|c|c|c|c|c|c|c|}
\hline Number & $\mathrm{Ca}(\mathrm{mg} / \mathrm{dl})$ & $\mathrm{P}(\mathrm{mg} / \mathrm{dl})$ & $\mathrm{Mg}(\mathrm{mg} / \mathrm{dl})$ & $\mathrm{D}_{3}(\mathrm{ng} / \mathrm{ml})$ & $\mathrm{PTH}(\mathrm{pg} / \mathrm{ml})$ & ALP $(\mathrm{U} / \mathrm{L})$ \\
\hline $\begin{array}{c}\text { Reference Values } \\
(14,19)\end{array}$ & $8.8-10.6$ & $2.7-4.5$ & $1.3-2.1$ & $20-32$ & $15-65$ & $70-390$ \\
\hline 1 & 5.3 & 9 & 1.2 & 4.02 & 1941 & 851 \\
\hline 2 & 4.7 & 11 & 1.1 & 4.48 & 784.7 & 623 \\
\hline 3 & 6.3 & 10 & 2.0 & 3.65 & 981.1 & 590 \\
\hline 4 & 6.2 & 8 & 1.9 & 3.04 & 704.6 & 885 \\
\hline 5 & 6.3 & 12 & 1.4 & $<3.00$ & 897.7 & 1250 \\
\hline 6 & 6.1 & 12 & 1.7 & $<3.00$ & 297.7 & 957 \\
\hline 7 & 5.9 & 5 & 2.0 & $<3.00$ & 506.3 & 968 \\
\hline Control & 8.5 & 2.5 & 1.5 & 27 & 45 & 187 \\
\hline Control & 9.3 & 3.7 & 2.0 & 31 & 55 & 248 \\
\hline Control & 9.5 & 3.5 & 1.7 & 26 & 28 & 350 \\
\hline Control & 10.1 & 3.1 & 1.4 & 23 & 64 & 369 \\
\hline
\end{tabular}

Table 2. Soil analysis results of the pasture.

Tablo 2. Meranın toprak analizi sonuçları.

\begin{tabular}{|c|c|c|c|c|c|}
\hline Depth $(\mathrm{cm})$ & Saturation with water $(\%)$ & Total salt $(\%)$ & $\mathrm{pH}$ & $\mathrm{CaCO}_{3}(\%)$ & Organic material (\%) \\
\hline $0-20$ & 73 & 0.056 & 7.7 & 1 & 4.92 \\
\hline
\end{tabular}

Soil analysis results indicated that low calcareous soils (\%1) characterized by $\mathrm{CaCO}_{3}$ level. Because of the problem occurred after moving this pastures and low calcium level in the pasture, the main cause of the problem was attributed the pasture. Changing to the pasture advised the owners but they didn't accept.

Kids had no clinical sings that newly born and 1 month of age were treated with combined calcium and vitamin D injections. Calcium at $7 \mathrm{ml}$, every three days, 5 times intramuscularly and vitamin D at $10.000 \mathrm{IU} / \mathrm{kg} \mathrm{BW}$ once a month for 5 month were administered. Although no new cases were observed after this treatment, the treatment was unsuccessful on kids that had obvious clinical sings.

\section{Discussion and Conclusion}

Fibrous osteodystrophy is a metabolic bone disease that characterized by increased osteoclastic resorption of bone and replacement by fibrous connective tissue. The most common cause of the disease is prolonged and excessive secretion of PTH $(14,22,25,26)$. Two types of hyperparathyroidism occur in animals and human being. Primary hyperparathyroidism is rare in domestic animals and may be linked to benign and malign parathyroid tumors or idiopathic bilateral parathyroid hyperplasia of the gland. The most commonly seen form is secondary hyperparathyroidism and the fundamental mechanism is a reduced concentration of calcium in the plasma with a relative increase in phosphorus $(25,26)$. Nutritional fibrous osteodystrophy is the most common pathology due to dietary insufficiency of calcium and/or excessive dietary phosphorus, which results in nutritional secondary hyperparathyroidism. Nutritional hyperparathyroidism generally occur in young animals fed diets with low calcium and relatively high phosphorus contents. One of the other forms of hyperparathyroidism is renal type characterized by failure to eliminate phosphor in the urine, which causes hyperphosphatemia. Whether it is nutritional or renal hyperparathyroidism, excessive secretion of PTH promotes bone reabsorption and softening of the bones $(22,26)$. Generally head bones effected and they become swollen, soft, deformed and predispose to pathological fractures $(5,10,14,24,25,27)$. In this study, caprine nutritional osteodystrophy was diagnosed based on clinical, biochemical, and pathological findings. The nutritional origin of the disease was proved through the absence of lesions in parathyroid glands and kidneys. Excessive PTH, ALP and low vitamin $\mathrm{D}_{3}$ blood levels were observed in affected kids compared to the controls. Low calcium and high phosphorous levels in serum supported the diagnosis of fibrous osteodystrophy. Because of the flocks not feed with bran the main cause of the low $\mathrm{Ca}$ levels attributed the low $\mathrm{CaCO}_{3}$ level of the pasture. 
In the cases of fibrous osteodystrophy, respiratory distress may result from proliferation of poorly ossified tissue that impinges on the nasal cavity. Metabolic bone disease is seen at sites of mechanical stress in adult animals, especially maxilla and mandible as a result of mastication and rumination $(22,26)$. Similar findings were also observed in this study, but exophthalmos was more common symptom in affected kids. In all cases, disease started at facial bones and in some cases extremity deformities accompanied the lesions.

The resultant compensatory hyperparathyroidism and its associated fibrous osteodystrophy are usually caused by a lack of dietary calcium in conjunction with an excess intake of phosphorous. The disease is known to develop in herbivores fed diets with a $\mathrm{Ca}: \mathrm{P}$ ratio of 0.8 or lower $(13,20)$. Other factors that may play a role include vitamin D deficiency (in housed animals), reduced calcium absorption due to endoparasitism, or calcium binding substances such as oxalate in the diet $(13,19)$. The exact nature of the nutritional abnormality in this study was not determined but nutritional etiology supported by soil analysis and responsive Ca treatment.

There is a little knowledge about treatment of the disease. This study showed that $\mathrm{Ca}$ and Vit D combinations can be used for both prophylactic and therapeutic aim in the affected flocks. But success of the treatment was related to severity of clinical signs.

\section{References}

1. Andrews AH, Ingram PL, Longstaffe JA (1983): Osteodystrophia fibrosa in young goats. Vet Rec, 112, 404406.

2. Arnold SA, Kram MA, Hintz HF, et al. (1973): Nutritional secondary hyperparathyroidism in the parakeet. Cornell Vet J, 64, 37-46.

3. Aslani MR, Movassaghi AR, Mohri M, et al. (2001): Outbreak of osteodystrophia fibrosa in young goats. J Vet Med-A, 48, 385-389.

4. Bandarra PM, Pavarini SP, Santos AS, et al. (2011): Nutritional fibrous osteodystrophy in goats. Pesqui Vet Bras, 31, 875-878.

5. Bas S, Bas A, López I, et al. (2005): Nutritional secondary hyperparathyroidism in rabbits. Domest Anim Endocrin 28, 380-390.

6. Bruckman VJ, Wriessnig K (2013): Improved soil carbonate determination by FT-IR and X-ray analysis. Environ Chem Lett, 11, 65-70.

7. Chen WR, Chen YD, Shi Y, et al. (2015): Vitamin D, parathyroid hormone and risk factors for coronary artery disease in an elderly Chinese population. J Cardiovasc Med (Hagerstown), 16, 59-68.

8. Clark CJ, Roeder PL, Dixon PM (1996): Nasal obstruction caused by nutritional osteodystrophia fibrosa in a group of Ethiopian horses. Vet Rec, 139, 568-570.

9. Crager CS, Nachreiner RF (1993): Increased parathyroid hormone concentration in a siamese kitten with nutritional secondary hyperparathyroidism. J Am Anim Hosp Assoc, 29, 331-336.

10. Dunn P (1994): The Goatkeeper's Veterinary Book. Farming Press, London.
11. Kawaguchi K, Braga IS 3rd, Takahashi A, et al. (1993): Nutritional secondary hyperparathyroidism occurring in a strain of German shepherd puppies. Jpn J Vet Res, 41, 89-96.

12. Luna LG (1968): Routine Staining Procedures. 32-47. In: Manual of Histologic Staining Methods of the Armed Forces Institute of Pathology, $3^{\text {rd }}$ ed. McGraw-Hill Book Company.

13. Lynch MJ, Slocombe RF, Harrington KE, et al. (1999): Fibrous osteodystrophy in Dromedary Camels (Camelus dromedarius). J Zoo Wildlife Med, 30, 577-583.

14. Radostits OM, Gay CC, Hinchcliff KW, et al. (2008): Bone Diseases. 632-637. In: Veterinary Medicine: A Textbook of Diseases of Cattle, Horses, Sheep, Pigs, and Goats, $10^{\text {th }}$ ed. Saunders Elsevier.

15. Roux P (2007): Mandibular fracture in a Lhasa Apso with secondary renal hyperparathyroidism. SAT, 149, 277-279.

16. Rusenov A, Nikolov Y, Simeonov R, et al. (2009): A case of fibrous osteodystrophy in a dog with secondary renal hyperparathyroidism. Bulg J Vet Med, 12, 212-218.

17. Sahinduran S, Ozmen O, Sevgisunar NS (2016): Multiorgan damage in a cow with diabetes mellitus. Vet J Ankara Univ, 63, 77-78.

18. Schwarz T, Störk CK, Megahy IW, et al. (2001): Osteodystrophia fibrosa in two guinea pigs. JAVMA, 219, 63-66.

19. Sidler-Lauff K, Boos A, Kraenzlin M, et al. (2010): Influence of different calcium supplies and a single vitamin $D$ injection on vitamin $D$ receptor and calbindin $D 9 k$ immunoreactivities in the gastrointestinal tract of goat kids. J Anim Sci, 88, 3598-3610.

20. Simesen MG (1980): Calcium, Phosphorus and Magnesium Metabolism. 610-611. In: Kaneko JJ (Ed.) Clinical Biochemistry of Domestic Animals. $3^{\text {rd }}$ ed. Academic Press.

21. Tasova H, Akın A (2013): Marmara bölgesi topraklarının bitki besin maddesi kapsamlarınin belirlenmesi, veri tabanının oluşturulması ve haritalanması. Soil-Water J, 2, 83-95.

22. Thompson K (2007): Bones and Joints. 82-88. In: Maxie MG (Ed.) Jubb, Kennedy, and Palmer's Pathology of Domestic Animals, Vol.1. $5^{\text {th }}$ ed. Elsevier.

23. Tomson FN, Lotshaw RR (1978): Hyperphosphatemia and hypocalcemia in lemurs. JAVMA, 173, 1103-1106.

24. Van Pelt RW, Caley MT (1974): Nutritional secondary hyperparathyroidism in Alaskan red fox kits. J Wildlife Dis, 10, 47-52.

25. Weisbrode SW (2007): Bone and Joints. 1075-1076. In: Mc Gavin MD, Zachary JF (Eds.) Pathologic Basis of Veterinary Disease, $4^{\text {th }}$ ed. Mosby Company.

26. Woodard JC (1997): Skeletal System. 917-922. In: Jones TC, Hunt RD, King NW (Eds.), Veterinary Pathology. William and Wilkins, Baltimore.

27. Yates NG, Hoffmann D, Seripto S (1987): Mandibular osteodystrophy fibrosa in Indonesian goats fed leucaena. Trop Anim Health Pro, 19, 121-126.

Geliş tarihi: 29.05.2015 / Kabul tarihi: 20.04.2016
Address for correspondence:
Prof.Özlem Özmen
Mehmet Akif Ersoy University,
Faculty of Veterinary Medicine,
Department of Pathology,
15030, Istiklal Yerleskesi, Burdur, Turkey
e-mail: ozlemozmen@mehmetakif.edu.tr 